\title{
ANALISIS NILAI ASET TETAP PADA LAPORAN KEKAYAAN MILIK DESA
}

\author{
Eko Febri Lusiono ${ }^{1}$ \\ Program Studi Akuntansi Keungan Perusahaan \\ Politeknik Negeri Sambas \\ Email: ekodelisa2004@gmail.com
}

\begin{abstract}
Abstrak
Temuan awal permasalahan penelitian ini bermula dari Laporan Kekayaan Milik Desa Semata tahun 2016 dan tahun 2017 yang dilaporkan tidak sesuai dengan Realisasi Anggaran Pendapatan dan Belanja (APB) Desa Semata tahun berkenaan, yaitu pada Penilaian Aset Tetap. Permendagri nomor 113 tahun 2014 tentang Pengelolaan Keuangan Desa dan Permendagri nomor 1 tahun 2016 tentang Pengelolaan Aset Desa sebagai dasar teori terapan untuk menyelesaikan masalah penelitian Penelitian terapan ini menggunakan teknik pengumpulan data triangulasi dan metode analisis data Miles and Hubermann. Hasil penelitian mengungkapkan bahwa Laporan Kekayaan Milik Desa Semata tahun 2016 dan 2017 tidak sesuai dengan peraturan terkait Pengelolaan Keuangan Desa dan Pengelolaan Aset Desa yang berlaku di Indonesia.Berdasarkan hasil wawancara, pihak terkait pengelolaan keuangan desa yaitu Kepala Desa, Sekretaris Desa, dan Bendahara Desa masih belum sempurna memahami teknis penyusunan Laporan Kekayaan Milik Desa, faktor tersebut menjadi salah satu penyebab masalah pada penyusunan Laporan Kekayaan Milik Desa. Rekomendasi terapan penyelesaian masalah telah disajikan pada analisis data penelitian ini.
\end{abstract}

Kata Kunci: Aset Desa, Aset Tetap, Laporan Kekayaan Milik Desa, Permendagri nomor 113 tahun 2014, Permendagri nomor 1 tahun 2016, Desa Semata.

\begin{abstract}
The initial findings of this research problem began with the 2016 and 2017 Semata Village Ownership Wealth Reports which were reported to be not in accordance with the Realization of the Semata Village Revenue and Expenditure (APB) for the year concerned, namely in Fixed Asset Valuation. Permendagri number 113 of 2014 concerning Village Financial Management and Permendagri number 1 of 2016 concerning Village Asset Management as the basis of applied theory to solve research problems. This applied research was conducted with triangulation data collection techniques and data analysis methods from Miles and Hubermann. The results of the study revealed that the 2016 and 2017 Semata Village Ownership Wealth Reports were not in accordance with regulations related to Village Financial Management and Village Asset Management in force in Indonesia. Based on interviews, the parties related to village financial management, namely the Village Head, Village Secretary, and Village Treasurer are still imperfect in understanding the technicalities of Village Property Wealth Reports, these factors being one of the causes of the Village Property Report. Applied recommendations for solving problems have been presented in the analysis of this research data.
\end{abstract}

Keywords: Village Assets, Fixed Assets, Village Property Assets, Permendagri number 113 in 2014, Permendagri number 1 in 2016, Semata Village.

\section{Pendahuluan}

Pada Undang-Undang nomor 6 Tahun 2014 pasal 1 diungkapkan bahwa Desa adalah kesatuan masyarakat hukum yang memiliki batas wilayah yang berwenang untuk mengatur dan mengurus urusan pemerintahan, kepentingan masyarakat setempat berdasarkan prakarsa masyarakat, hak asal usul, dan/atau hak tradisional yang diakui dan dihormati dalam sistem pemerintahan Negara Kesatuan Republik Indonesia. Kewenangan untuk mengatur dan mengurus urusan pemerintahan desa dilakukan oleh Pemerintah Desa terdiri dari Kepala Desa dan Perangkat Desa sebagai unsur penyelenggara Pemerintahan Desa. 
Pemerintah Desa dalam mengatur dan mengurus pemerintahan erat kaitannya bagaimana Pemerintah desa mengelola keuangan desa dalam melaksanakan pembangunan di Desa. Pada Peraturan Menteri Dalam Negeri (Permendagri) nomor 113 tahun 2014 tentang Pengelolaan Keuangan Desa telah diatur dengan jelas dan rinci bagaimana Pemdes melakukan pengelolaan keuangan desa. Pada pasal 1 ayat 6 , diungkapkan bahwa pengelolaan keuangan desa meliputi perencanaan, pelaksanaan, penatausahaan, pelaporan, dan pertanggungjawaban keuangan desa. Pada pasal 2 dan 3 diungkapkan bahwa pemegang kekuasaan pengelolaan keuangan desa dan kepemilikan kekayaan desa yang dipisahkan adalah Kepala Desa, serta Kepala Desa dalam pengelolaan keuangan desa berdasarkan asas transparan, akuntabel, partisipatif, serta dilakukan dengan tertib dan disiplin anggaran.

Berdasarkan kajian teori awal pada sebagian regulasi tentang Desa dan Pengelolaan Keuangan Desa yaitu pada Undang - Undang nomor 6 tahun 2014 tentang Desa dan Permendagri nomor 113 tahun 2014 diatas, peneliti tertarik untuk melakukan kajian dilapangan terkait implementasi peraturan tersebut oleh Pemerintah Desa.

Pemerintah Desa Semata, Kecamatan Tanggaran, Kabupaten Sambas, Kalimantan Barat adalah pihak pemerintah desa yang telah bersedia dijadikan objek penelitian bagi peneliti dalam melakukan kajian dilapangan terkait implementasi pengelolaan keuangan desa. Kepala Desa Semata berdasarkan asas transparan dan partisipatif memberikan keleluasaan kepada peneliti untuk melakukan penelitian dan diharapkan pengelolaan keuangan Desa Semata dapat akuntabel.

Kajian dilapangan terkait implementasi pengelolaan keuangan desa, peneliti tertarik pada data laporan yang diterima peneliti dari Pemerintah Desa Semata terkait pada tahapan akhir pengelolaan keuangan yaitu Pertanggungjawaban, berdasarkan Permendagri nomor 113 pasal 38 bahwa Kepala Desa menyampaikan laporan pertanggungjawaban realisasi APBDesa kepada Bupati/Walikota setiap akhir tahun. Laporan yang dimaksud adalah laporan pertanggungjawaban realisasi pelaksanaan APBDesa tahun anggaran berkenaan, laporan kekayaan milik desa per 31 Desember tahun anggaran berkenaan, dan laporan program pemerintah dan pemerintah daerah masuk ke desa.

TABEL 1

Temuan Awal PerbedaAn Nilai Aset Tetap PADA LAPORAN KEKAYAAN MILIK DESA DAN LAPORAN REAL ISASI APB DESA SEMATA TAHUN 2016 DAN TAHUN 2017

\begin{tabular}{|c|c|c|}
\hline Perubahan Nilai Aset Tetap & Realisasi & Selisih \\
Berdasarkan Laporan & APB Desa & Perbedaan \\
Kekayaan Milik Desa & Semata & Nilai Aset \\
Semata Per Tahun 2016 dan & Berpengaruh & Tetap \\
Per Tahun 2017 & Pada & Dilaporkan \\
\hline
\end{tabular}

\begin{tabular}{|c|c|c|c|}
\hline \multicolumn{2}{|c|}{ (Rp) } & $\begin{array}{c}\text { Perubahan } \\
\text { Nilai Aset } \\
\text { Tetap } \\
\text { (Rp) }\end{array}$ & (Rp) \\
\hline \multicolumn{2}{|c|}{ Aset Tetap Tercatat } & Tahun 2016 & Tahun 2016 \\
\hline Tahun 2015 & 332.186 .007 & \multirow[b]{3}{*}{542.033 .602} & \multirow[b]{3}{*}{530.662 .459} \\
\hline Tahun 2016 & 343.557 .150 & & \\
\hline $\begin{array}{l}\text { Perubahan } \\
\text { Nilai Aset } \\
\text { Tetap Per } \\
\text { Tahun } 2016\end{array}$ & 11.371.143 & & \\
\hline \multicolumn{2}{|c|}{ Aset Tetap Tercatat } & Tahun 2017 & Tahun 2017 \\
\hline Tahun 2016 & $624,301.048$ & \multirow[b]{3}{*}{ 771.836.850 } & \multirow[b]{3}{*}{ 742.738.798 } \\
\hline Tahun 2017 & 653.399 .100 & & \\
\hline $\begin{array}{l}\text { Perubahan } \\
\text { Nilai Aset } \\
\text { Tetap Per } \\
\text { Tahun } 2017\end{array}$ & 29.098.052 & & \\
\hline
\end{tabular}

Pada tabel 1.1 diatas, temuan awal yang menarik untuk dikaji oleh peneliti pada Laporan Kekayaan Milik Desa (LKMD) Semata per 31 Desember tahun 2016 dan tahun 2017 adalah:

1) Perubahan nilai aset tetap tercatat pada LKMD Semata periode 31 Desember 2016 sebesar Rp. 11.371.143,00 tidak sesuai dengan realisasi APB Desa Semata tahun 2016 berpengaruh pada perubahan nilai aset tetap yakni sebesar Rp. 542.033.602,00. Sehingga terdapat selisih perbedaan nilai aset tetap dilaporkan sebesar Rp. 530.662.459,00.

2) Perubahan nilai aset tetap tercatat pada LKMD Semata periode 31 Desember 2017 sebesar Rp. 29.098.052,00 tidak sesuai dengan realisasi APB Desa Semata tahun 2017 berpengaruh pada perubahan nilai aset tetap yakni sebesar Rp. 771.836.850,00. Sehingga terdapat selisih perbedaan nilai aset tetap dilaporkan sebesar Rp. 742.738.798,00.

Merujuk pada Permendagri nomor 1 tahun 2016 tentang Pengelolaan Aset Desa pasal 1 ayat 5, Aset Desa adalah barang milik Desa yang berasal dari kekayaan asli milik Desa, dibeli atau diperoleh atas beban Anggaran Pendapatan dan Belanja Desa (APB Desa) atau perolehan Hak lainnya yang sah.

Berdasarkan dari temuan awal perbedaan nilai aset tetap pada LKMD dan laporan realisasi APB Desa Semata tahun 2016 dan 2017 serta menujuk pada dasar teori Aset Desa berdasarkan Permendagri nomor 1 tahun 2016 pasal 1 ayat 5, mendasari peneliti untuk melakukan penelitian ini. Rumusan masalah penelitian ini adalah:

1) Apakah nilai aset tetap pada Laporan Kekayaan Milik Desa Semata tahun 2016 dan 2017 tidak sesuai dengan pasal 1 ayat 5 Permendagri nomor 1 tahun 2016 tentang Pengelolaan Aset Desa?

2) Apakah rekomendasi agar nilai aset tetap pada Laporan Kekayaan Milik Desa Semata tahun 2016 dan 2017 sesuai dengan pasal 1 ayat 5 Permendagri nomor 1 tahun 2016 tentang Pengelolaan Aset Desa? 


\section{Tinjauan Pustaka}

\section{a) Desa}

Berdasarkan Undang - Undang Republik Indonesia nomor 6 tahun 2014 tentang Desa pasal 1 ayat 1 dijelaskan bahwa Desa adalah desa dan desa adat atau yang disebut dengan nama lain, selanjutnya disebut Desa, adalah kesatuan masyarakat hukum yang memiliki batas wilayah yang berwenang untuk mengatur dan mengurus urusan pemerintahan, kepentingan masyarakat setempat berdasarkan prakarsa masyarakat, hak asal usul, dan/atau hak tradisional yang diakui dan dihormati dalam sistem pemerintahan Negara Kesatuan Republik Indonesia.

Pasal pada 18 dan 19 diungkapkan bahwa kewenangan Desa meliputi kewenangan di bidang penyelenggaraan Pemerintahan Desa, pelaksanaan Pembangunan Desa, pembinaan kemasyarakatan Desa, dan pemberdayaan masyarakat Desa berdasarkan prakarsa masyarakat, hak asal usul, dan adat istiadat Desa. Kewenangan Desa meliputi kewenangan berdasarkan hak asal usul; kewenangan lokal berskala Desa; kewenangan yang ditugaskan oleh Pemerintah, Pemerintah Daerah Provinsi, atau Pemerintah Daerah Kabupaten/Kota; dan kewenangan lain yang ditugaskan oleh Pemerintah, Pemerintah Daerah Provinsi, atau Pemerintah Daerah Kabupaten/Kota sesuai dengan ketentuan peraturan perundang-undangan.

\section{b) Pemerintahan dan Pemerintah Desa}

Berdasarkan Undang - Undang Republik Indonesia nomor 6 tahun 2014 tentang Desa pasal 1 ayat 2 dan 3, diungkapkan bahwa Pemerintahan Desa adalah penyelenggaraan urusan pemerintahan dan kepentingan masyarakat setempat dalam sistem pemerintahan Negara Kesatuan Republik Indonesia. Sedangkan Pemerintah Desa adalah Kepala Desa atau yang disebut dengan nama lain dibantu perangkat Desa sebagai unsur penyelenggara Pemerintahan Desa.

\section{c) Keuangan Desa dan Pengelolaan Keuangan Desa}

Berdasarkan Peraturan Menteri Dalam Negeri nomor 113 tahun 2014 tentang Pengelolaan Keuangan Desa pasal 1 ayat 5 dan 6, diungkapkan bahwa Keuangan Desa adalah semua hak dan kewajiban Desa yang dapat dinilai dengan uang serta segala sesuatu berupa uang dan barang yang berhubungan dengan pelaksanaan hak dan kewajiban Desa. Sedangkan Pengelolaan Keuangan Desa adalah keseluruhan kegiatan yang meliputi perencanaan, pelaksanaan, penatausahaan, pelaporan, dan pertanggungjawaban keuangan desa.

\section{d) Laporan Kekayaan Milik Desa (LKMD) dan Laporan Pertanggungjawaban Realisasi APB Desa}

Berdasarkan lampiran Peraturan Menteri Dalam Negeri nomor 113 tahun 2014 tentang Pengelolaan Keuangan Desa, Laporan Kekayaan Milik Desa memuat laporan tentang Aset Desa dan Kewajiban Jangka Pendek. Aset Desa terdiri dari aset lancar dan aset tidak lancar. Aset lancar bersumber dari kas desa, piutang, dan persediaan. Aset tidak lancar bersumber dari investasi permanen, aset tetap, dana cadangan, dan aset tidak lancar lainnya, sedangkan Laporan Pertanggungjawaban Realisasi APB Desa memuat informasi tentang Anggaran dan Realisasi pada:

1) pendapatan: pendapatan asli desa, pendapatan transfer, dan pendapatan lain lain.

2) belanja: belanja bidang penyelenggaraan pemerintah desa, belanja bidang pelaksanaan pembangunan desa, belanja bidang pembinaan kemasyarakatan, belanja bidang pemberdayaan masyarakat, dan bidang tak terduga.

3) pembiayaan: penerimaan pembiayaan dari SILPA (Sisa Lebih Pembiayaan Anggaran) tahun berkenaan, pencairan dana cadangan, dan hasil kekayaan desa yang dipisahkan.

Secara lengkap format Laporan Kekayaan Milik Desa dan Laporan Pertanggungjawaban Realisasi APB Desa terdapat pada lampiran artikel ilmiah ini.

\section{e) Aset Desa dan Pengelolaan Aset Desa}

Berdasarkan Peraturan Menteri Dalam Negeri nomor 1 tahun 2016 tentang Pengelolaan Aset Desa pasal 1 ayat 5 dan 6 diungkapkan bahwa Aset Desa adalah barang milik Desa yang berasal dari kekayaan asli milik Desa, dibeli atau diperoleh atas beban Anggaran Pendapatan dan Belanja Desa (APB Desa) atau perolehan Hak lainnya yang sah. Sedangkan Pengelolaan Aset Desa merupakan rangkaian kegiatan mulai dari perencanaan, pengadaan, penggunaan, pemanfaatan, pengamanan, pemeliharaan, penghapusan, pemindah tanganan, penatausahaan, pelaporan, penilaian, pembinaan, pengawasan dan pengendalian aset Desa.

\section{Metode Penelitian}

\section{a) Jenis Penelitian}

Menurut Indriantoro (2009) jenis atau klasifikasi penelitian bisnis berdasarkan tujuannya terdapat dua buah yaitu penelitian dasar dan penelitian terapan. Penelitian dasar adalah penelitian yang betujuan untuk mengembangkan teori, sedangkan penelitian terapan adalah penelitian yang menekankan pada pemecahan masalah. Penelitian ini adalah merupakan penelitian terapan yang menfokuskan pada evaluasi terhadap tindakan, program, atau kegiatan yang telah dilakukan.

Memperhatikan lebih pada temuan awal masalah yang diungkapkan pada pendahuluan diatas, terungkap bahwa tindakan yang telah dilakukan oleh 
Pemerintah Desa Semata dalam penyusunan Laporan Kekayaan Milik Desa tahun 2016 dan 2017 tidak sesuai dengan Permendagri nomor 113 tahun 2014 beserta lampiran format penyusunan laporan karena terindikasi bahwa realisasi APB Desa Semata tahun 2016 dan tahun 2017 yang berpengaruh pada perubahan nilai aset tetap tidak dimasukan pada Laporan Kekayaan Milik Desa. Penelitian terapan ini dilakukan untuk memecahkan masalah tersebut.

\section{b) Lokasi Penelitian}

Lokasi penelitian ini dilakukan di kantor desa Semata kecamatan Tangaran kabupaten Sambas Kalimantan Barat.

\section{c) Sumber Data Penelitian}

Pada penelitian ini, sumber data penelitian bersumber pada data primer dan data sekunder. Data primer merupakan sumber data penelitian yang diperoleh secara langsung dari sumber asli, sedangkan data sekunder merupakan sumber data penelitian yang diperoleh peneliti secara tidak langsung melalui media perantara (Indriantoro, 2009). Menurut Sugiyono (2008) sumber primer adalah sumber data yang langsung memberikan data kepada pengumpul data, dan sumber sekunder merupakan sumber yang tidak langsung memberikan data kepada pengumpul data.

Data primer penelitian ini misalnya adalah berupa catatan wawancara langsung dengan pengelola keuangan Desa Semata, Laporan Realiasasi APB Desa Semata tahun 2016 dan tahun 2017, Laporan Kekayaan Milik Desa Semata tahun 2016 dan tahun 2017. Data sekunder penelitian ini misalnya adalah berupa undang-undang, peraturan menteri, dan beberapa buku literatur.

\section{d) Teknik Pengumpulan Data Penelitian}

Menurut Sugiyono (2008), teknik pengumpulan data triangulasi adalah teknik yang menggabungkan dari berbagai teknik pengumpulan data dan sumber data yang ada. Pada penelitian ini, teknik pengumpulan data triangulasi yang dilakukan yaitu menggabungkan teknik observasi partisipatif, wawancara mendalam, dan dokumentasi.

Teknik observasi partisipatif dilakukan dengan cara peneliti terlibat langsung dengan pemerintah Desa Semata dalam menemukan dan menyelesaikan masalah pada Penyusunan Laporan Kekayaan Milik Desa Semata. Teknik wawancara mendalam, peneliti lakukan dengan cara memberikan pertanyaan terstruktur kepada pihak terkait (Kepala Desa, Sekretaris, Bendahara) tentang tahapan yang dilakukan pada Penyusunan Laporan Kekayaan Milik Desa Semata yang disesuaikan dengan Permendagri nomo 113 tahun 2014 dan peraturan terkait. Teknik dokumentasi, peneliti lakukan dengan cara mendokumentasikan berkas penting, diantaranya yaitu:

1) Salinan Laporan Kekayaan Milik Desa Semata tahun 2016 dan tahun 2017.

2) Salinan Laporan Pertanggungjawaban Realisasi APB Desa Semata tahun 2016 dan tahun 2017.

3) Salinan Undang-Undang nomor 6 tahun 2014 tentang Desa.

4) Salinan Permendagri nomor 113 tahun 2014 tentang Pengelolaan Keuangan Desa beserta lampirannya.

5) Salinan Permendagri nomor 1 tahun 2016 tentang Pengelolaan Aset Desa.

6) Beberapa buku referensi metode penelitian.

\section{e) Metode Analisis Data}

Pada penelitian ini, analisis data dilakukan di kampus, saat di kantor Desa Semata, dan sesudah dari kantor Desa Semata. Hal tersebut senada yang disampaikan oleh Sugiyono (2008), yaitu pada penelitian kualitatif, analisis data dilakukan sejak sebelum dilapangan, selama dilapangan, dan setelah selesai di lapangan.

Analisis data pada penelitian ini menggunakan analisis data Miles and Hubermann. Menurut Sugiyono (2008), analisis Miles and Hubermann terdiri dari aktivitas reduksi data, penyajian data, penarikan kesimpulan dan verifikasi. Reduksi data adalah proses merangkum, memilih hal-hal yang pokok, menfokuskan pada hal penting, dicari tema dan polanya dan membuang yang tidak perlu. Pada tahap ini peneliti melakukan proses reduksi data dengan cara merangkum dan memilih data yang berkaitan langsung dengan masalah penelitian yaitu data Laporan Kekayaan Milik Desa Semata tahun 2016 dan 2017, Laporan Pertanggungjawaban Realisasi APB Desa Semata tahun 2016 dan 2017, UU nomor 6 tahun 2014 tentang Desa, Permendagri nomor 113 tahun 2014 tentang Pengelolaan Keuangan Desa beserta lampirannya, dan Permendagri nomor 1 tahun 2016 tentang Pengelolaan Aset Desa. Penyajian data dalam penelitian kualitatif berupa uraian singkat/teks bersifat naratif, bagan, hubungan antar kategori, flowchat, dan sejenisnya. Pada tahap ini, peneliti akan menganalisis dan menentukan inti permasalahan yang diungkapkan pada temuan awal masalah penelitian ini, yaitu kesalahan Penyusunan Laporan Kekayaan Milik Desa Semata tahun 2016 dan 2017. Selanjutnya, peneliti akan mengajukan penyelesaian permasalahan dengan menerapkan dasar teori yang benar sesuai dengan Permendagri no 113 tahun 2014 beserta lampirannya.

Penarikan kesimpulan dan verifikasi dilakukan berdasarkan pada kesimpulan awal, kemudian diverifikasi dengan data yang telah terkumpul, jika data valid mendukung kesimpulan awal, maka 
kesimpulan tersebut adalah kesimpulan kredibel. Pada penelitian ini, peneliti akan menarik simpulan dan mengajukan Laporan Kekayaan Milik Desa Semata yang benar dan telah direvisi dan diverifikasi berdasarkan data keuangan Desa Semata, Permendagri nomor 113 tahun 2014 tentang Pengelolaan Keuangan Desa berserta lampirannya, dan Permendagri nomor 1 tahun 2016.

\section{Hasil dan Pembahasan}

Berdasarkan temuan awal permasalahan, sumber data, teknik pengumpulan data, dan metode analisis data penelitian yang diajukan. Peneliti memaparkan hasil penelitian dibagi menjadi dua bagian, yaitu:

a) Terapan Penyusunan Laporan Kekayaan Milik Desa Semata tahun 2016 dan 2017.

Analisis data Miles and Hubermann berupa aktivitas reduksi data penelitian, mengarahkan agar peneliti lebih memfokuskan pada inti permasalahan serta terapan penyelesaian masalah. Maka, berdasarkan uraian fokus temuan masalahnya adalah:

1) Nilai aset desa, terutama aset tetap yang tampil pada Laporan Kekayaan Milik Desa Semata tahun 2016 tidak sesuai dengan nilai Realisasi APB Desa Semata tahun 2016 berpengaruh pada perubahan nilai aset tetap, terdapat selisih perbedaan nilai aset tetap dilaporkan tahun 2016 senilai Rp. 530.662.459,00.

2) Nilai aset desa, terutama aset tetap yang tampil pada Laporan Kekayaan Milik Desa Semata tahun 2017 tidak sesuai dengan nilai

\begin{tabular}{|c|c|c|c|}
\hline Akun & $\begin{array}{c}\text { LKMD } \\
\text { Tahun } 2016 \\
\text { Sebelum } \\
\text { Perubahan }\end{array}$ & $\begin{array}{c}\text { LKMD } \\
\text { Tahun } 2016 \\
\text { Setelah } \\
\text { Perubahan }\end{array}$ & $\begin{array}{c}\text { Selisih } \\
\text { Perubahan } \\
\text { sesuai } \\
\text { realisasi APB } \\
\text { Desa Semata } \\
\text { tahun } 2016\end{array}$ \\
\hline & \multicolumn{3}{|c|}{ (dalam jutaan rupiah) } \\
\hline Aset Lancar & - & - & - \\
\hline Kas Desa & 4,181 & 4,181 & \\
\hline Piutang & - & & \\
\hline Persediaan & - & & \\
\hline $\begin{array}{l}\text { Jumlah aset } \\
\text { lancar }\end{array}$ & 4,181 & 4,181 & \\
\hline $\begin{array}{l}\text { Aset tidak } \\
\text { lancar }\end{array}$ & - & - & \\
\hline $\begin{array}{l}\text { Investasi } \\
\text { Permanen }\end{array}$ & - & - & \\
\hline Aset Tetap & 343,557 & 874,219 & 530,662 \\
\hline $\begin{array}{l}\text { Dana } \\
\text { cadangan }\end{array}$ & - & - & \\
\hline $\begin{array}{l}\text { Aset tidak } \\
\text { lancar } \\
\text { lainnnya }\end{array}$ & - & - & \\
\hline $\begin{array}{l}\text { Jumlah aset } \\
\text { tidak lancar }\end{array}$ & 343,557 & 874,219 & \\
\hline Jumlah aset & 347,738 & 878,400 & \\
\hline $\begin{array}{l}\text { Kewajiban } \\
\text { jangka } \\
\text { pendek }\end{array}$ & - & - & \\
\hline
\end{tabular}

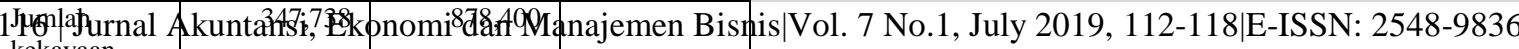
kekayaan bersih
Realisasi APB Desa Semata tahun 2017 berpengaruh pada perubahan nilai aset tetap, terdapat selisih perbedaan nilai aset tetap dilaporkan tahun 2017 senilai Rp. 742.738.798,00.

TABEL 2

REKOMENDASI PERUbahan Nilai ASET TetaP PADa LaPORAN KeKayaAn Milik DeSa (LKMD) Semata Tahun 2016 Sesuai REALISASI APB DESA SEMATA TAHUN 2016

Dasar teori digunakan untuk menganalisis adalah berdasarkan Permendagri 1 tahun 2016 tentang Pengelolaan Aset Desa pasal 1 ayat 5 da6 diungkapkan bahwa Aset Desa adalah barang

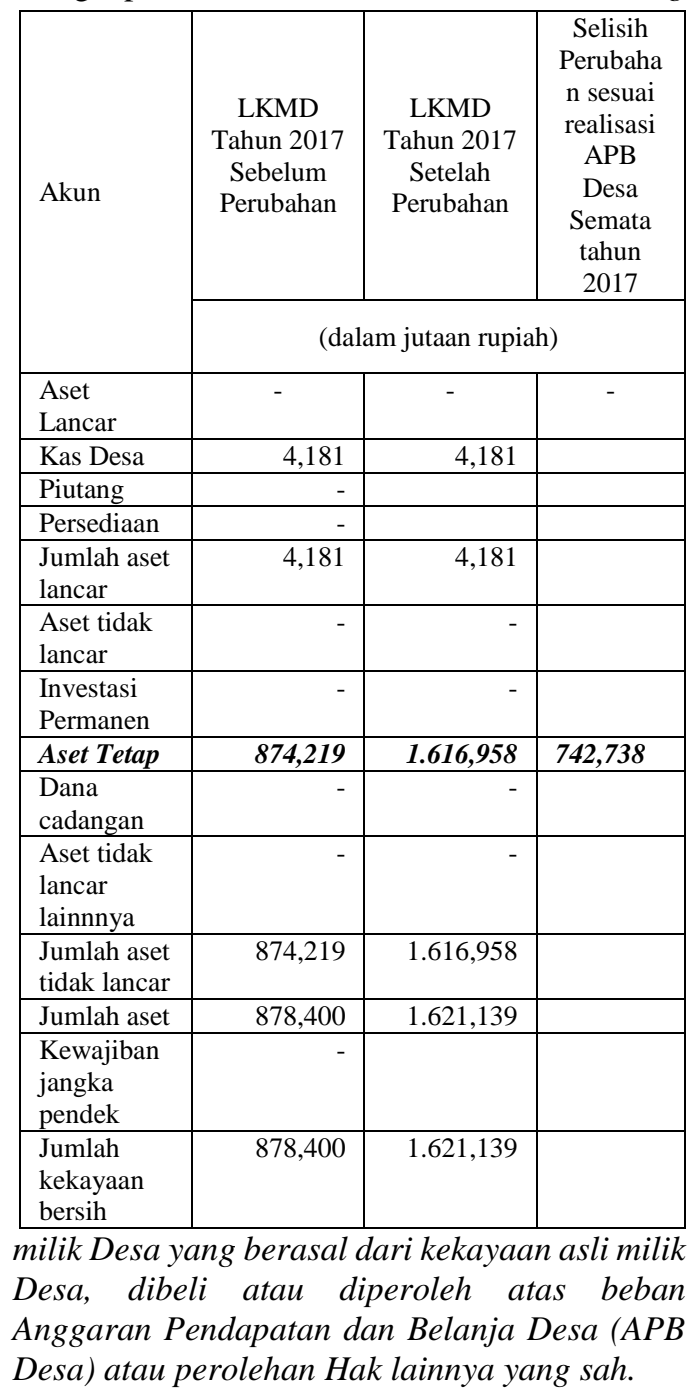

TABEL 3

REKOMENDASI PERUBAHAN NILAI ASET TETAP PADA LAPORAN KekayaAn Milik DeSa (LKMD) Semata Tahun 2017 Sesuai REALISASI APB DESA SEMATA TAHUN 2017

Maka, solusi terapan penyelesaian masalahnya adalah pengajuan / rekomendasi (tampak pada tabel 1.2 dan 1.3) perubahan nilai aset tetap yang tampil pada Laporan Kekayaan Milik Desa Semata tahun 2016 dan 2017 sesuai dengan Laporan Pertanggungjawaban Realisasi RAB Desa Semata tahun 2016 dan 2017. 
b) Wawancara Mendalam Kepada Pihak Terkait

Pada proses wawancara mendalam, peneliti lakukan dengan cara memberikan pertanyaan terstruktur kepada pihak terkait (Kepala Desa, Sekretaris, Bendahara) tentang tahapan yang dilakukan pada Penyusunan Laporan Kekayaan Milik Desa Semata yang disesuaikan dengan Permendagri nomo 113 tahun 2014 dan peraturan terkait lainnya. Berdasarkan hasil wawancara mendalam, berikut dibawah ini adalah deskriptif naratifnya:

1) Seluruh pihak terkait telah diberikan amanah pada jabatan masing-masing sejak 1 Januari tahun 2015 hingga penelitian ini dilakukan.

2) Seluruh pihak terkait telah membaca beberapa aturan pemerintah terkait desa dan pengelolaan keuangan desa. Aturan pemerintah yang dimaksud adalah:

a. Undang-Undang nomor 6 tahun 2014 tentang Desa.

b. Permendagri nomor 113 tahun 2014 tentang Pengelolaan Keuangan Desa.

c. Lampiran - lampiran Permendagri nomor 113 tahun 2014 tentang Pengelolaan Keuangan Desa yang berisi tentang salah satunya yaitu format Laporan Kekayaan Milik Desa.

d. Permendagri nomor 1 tahun 2016 tentang Pengelolaan Aset Desa.

3) Berdasarkan Permendagri nomor 113 tahun 2014 tentang Pengelolaan Keuangan Desa, bahwa pihak yang berwenang dan bertugas melakukan penyusunan Laporan Kekayaan Milik Desa adalah Sekretaris Desa. Hasil wawancara, pihak terkait yang mengetahui tentang wewenang dan tugas tersebut adalah bendahara desa.

4) Pertanyaan tentang apakah pihak terkait pernah diberikan bimbingan teknis dari pemerintah daerah atau pusat tentang tahapan penyusunan Laporan Kekayaan Milik Desa ? Pihak terkait yang pernah mengikuti bimbingan teknis adalah Kepala Desa dan diakui sangat tidak paham karena berkenaan Kepala Desa sudah cukup berumur/tua.

5) Pertanyaan tentang apakah memahami secara teknis bagaimana menentukan nilai Aset tetap pada Laporan Kekayaan Milik Desa yang disesuaikan dengan Laporan Realisasi APB Desa pada akhir tahun pelaporan ? Seluruh pihak terkait tidak memahami bagaimana cara menentukannya.

6) Pertanyaan tentang apakah Laporan Kekayaan Milik Desa selalu dilaporkan setiap tahun kepada Bupati. Seluruh pihak terkait mengakui telah membuat laporan tersebut dan laporan lainnya sejak tahun 2015.

7) Pertanyaan tentang apakah laporan pertanggungjawaban realisasi pelaksanaan APB Desa setiap tahun kepada Bupati beserta lampirannya, pihak terkait pernah mendapatkan teguran atau penjelasan apakah laporan yang disampaikan benar atau salah ? Pihak terkait menjawab, mereka hanya menjalankan perintah membuat laporan sesuai kemampuan maksimal, tentang benar atau salah laporan yang disusun belum pernah ada evaluasi.

\section{Simpulan}

Merujuk pada rangkaian tahapan penulisan hasil penelitian diatas, makan simpulan penelitian ini adalah:

1) Laporan Kekayaan Milik Desa Semata tahun 2016 dan 2017 terdapat masalah pada penyusunannya, terutama pada penentuan nilai aset tetap yang tidak disesuaikan realisasi APB Desa tahun 2016 dan 2017 yang merujuk pada pasal 1 ayat 5 Permendagri nomor 1 tahun 2016 tentang Pengelolaan Aset Desa. Hal tersebut diperkuat dengan hasil wawancara mendalam kepada pihak terkait, bahwa seluruh pihak terkait tidak memahami bagaimana menentukan nilai aset tetap tersebut.

2) Rekomendasi terapan sebagai solusi pemecahan masalah telah disajikan berdasarkan data Laporan Pertanggungjawaban Realisasi APB Desa Semata Tahun 2016 dan 2017.

3) Berdasarkan hasil wawancara mendalam, sebagian besar pihak terkait masih belum sempurna memahami tentang teknis Penyusunan Laporan Kekayaan Milik Desa beserta aturan terkaitnya.

\section{Daftar Pustaka}

A. Peraturan Menteri Dalam Negeri Nomor 113 Tahun 2014 Tentang Pengelolaan Keuangan Desa.

B. Peraturan Menteri Dalam Negeri Nomor 1 Tahun 2016 Tentang Pengelolaan Aset Desa.

C. Lampiran Peraturan Menteri Dalam Negeri Nomor 113 Tahun 2014 Tentang Pengelolaan Keuangan Desa.

D. Sugiyono, Metode Penelitian Bisnis, cetakan ke12, Alfabeta - Bandung, 2008.

E. Indriantoro, Metode Penelitian Bisnis Untuk Akuntansi dan Manajemen, cetakan ke-3, BPFE - Yogyakarta, 2009. 


\section{Lampiran}

Format Laporan Kekayaan Milik Desa Sesuai Permendagri Nomor 113 Tahun 2014

\begin{tabular}{|c|c|c|}
\hline Uraian & $\begin{array}{c}\text { Tahun N (Tahun Periode } \\
\text { Pelaporan) }\end{array}$ & $\begin{array}{l}\text { Tahun N-1 (Tahun } \\
\text { Sebelumnya) }\end{array}$ \\
\hline \multicolumn{3}{|l|}{$\begin{array}{l}\text { I. Aset Desa } \\
\text { A. Aset Lancar } \\
\text { 1. Kas Desa } \\
\text { a. Uang kas dibendahara desa } \\
\text { b. Rekening kas desa } \\
\text { 2. Piutang } \\
\text { a. Piutang Sewa Tanah } \\
\text { b. Piutang Sewa gedung } \\
\text { c. Dst........ } \\
\text { 3. Persediaan } \\
\text { a. Kertas Segel } \\
\text { b. Materai } \\
\text { c. Dst........ }\end{array}$} \\
\hline \multicolumn{3}{|l|}{ Jumlah Aset Lancar } \\
\hline $\begin{array}{l}\text { B. Aset Tidak Lancar } \\
\text { 1. Investasi Permanen } \\
\quad-\text { Penyertaan Modal Pemerintah desa } \\
\text { 2. Aset Tetap } \\
-\quad \text { Tanah } \\
- \text { Peralatan dan Mesin } \\
- \text { Gedung dan Bangunan } \\
- \text { Jalan, Jaringan dan Irigasi } \\
- \text { Aset Tetap Lainnya } \\
\text { 3. Dana Cadangan } \\
\text { - Dana Cadangan } \\
\text { 4. Aset Tidak Lancar Lainnya } \\
\end{array}$ & & \\
\hline Jumlah Aset Tidak Lancar & & \\
\hline Jumlah Aset $(\mathrm{A}+\mathrm{B})$ & & \\
\hline II. Kewajiban Jangka Pendek & & \\
\hline Jumlah Kewajiban Jangka Pendek & & \\
\hline Jumlah Kekayaan Bersih ( I - II) & & \\
\hline
\end{tabular}

